\title{
PENGEMBANGAN WEBLOG SEBAGAI SUMBER BELAJAR PADA MATERI PENCEMARAN UNTUK SISWA SMP
}

\author{
Putri Rahma Dianti $^{1)}$, Evi Suryawati' ${ }^{2)}$, Mariani Natalina ${ }^{3)}$ \\ E-mail: Putri.rahma5072@student.unri.ac.id \\ 1)2)3) Program Studi Pendidikan Biologi, FKIP Universitas Riau
}

\begin{abstract}
Reflective thinking skills for solving environmental problems in junior high school students need to improved, one of which is the development of learning resources. This research aims develop weblog media about environmental contamination material to determine the reflective thinking skills of junior high school students. The development of a weblog as a learning medium used the ADDIE model (Analyze, Design, Development, Implementation and Evaluation). In this research up to the development phase . The weblog design has gone through the validation phase using a validation sheet. Student responses were collected using a questionnaire and reflective thinking skills using multiple choice test. The developed weblog has been tested on 20 students of $8^{\text {th }}$ grade. The results showed that the use of blogging media positively impacted students' reflective thinking skills, given the increase in mean pre-test and post-test scores from a score of 69.5 to 82 . The increase in reflective thinking skills was seen in of the three indicators of reflective thinking, namely reacting, elaborating and contemplating. The use of blogging media to reinforce thinking skills is also supported by the results of student responses with an average result of $92,8 \%$ for aspects of reflective thinking. The results show that the developed weblog is in a very feasible category as a learning resource on pollution and global warming material to strengthen students' reflective thinking
\end{abstract}

Keywords: Junior high school, Reflective thinking ability, Weblog

\section{PENDAHULUAN}

Pembelajaran IPA meliputi berbagai aspek kehidupan, selain sebagai ilmu yang mempelajari tentang pengetahuan alam, dalam pembelajaran IPA juga dipelajari tentang permasalahan yang terjadi di lingkungan sekitar. Permasalahan lingkungan dapat berkaitan dengan permasalahan sosial atau dikenal dengan isu sosial sains. Isu-isu sosial sains dapat berupa isu pemanasan global, kebakaran hutan pencemaran lingkungan dan lainnya (A.W Subiantoro et al., 2013). Permasalahan lingkungan tersebut merupakan isu kontekstual yang dapat ditemukan siswa sebagai pembelajaran dalam proses pemecahan masalah. Menurut Endah Tri Priyatni et al. (2017), pemecahan permasalahan isu lingkungan dapat dilakukan dengan meningkatkan pengetahuan dan pemahaman. Pemahaman mengenai isu-isu kritis lingkungan dapat menjadi salah satu upaya untuk mengubah perilaku siswa (Vania Zulfa et al., 2016). Kemampuan pemecahan masalah tersebut perlu didukung oleh kemampuan berpikir salah satunya yaitu kemampuan berpikir reflektif. Kemampuan berpikir reflektif melibatkan kemampuan berpikir tingkat tinggi, yaitu mengamati, menganalisis, menafsirkan masalah, membuat kesimpulan, menilai, mempertimbangkan strategi dan tindakan (Endah Tri Priyatni et al., 2017). E. Suryawati et al. (2020) juga menyatakan bahwa kemampuan berpikir diperlukan sebagai mediator untuk kepekaan lingkungan. Pengembangan kemampuan berpikir dimulai dengan pengetahuan untuk menghasilkan sikap dan pengambilan keputusan. Kemampuan berpikir reflektif pada siswa tidak dapat berkembang secara 
langsung, melainkan melalui tahapan pengembangan. Pengembangan dasar kemampuan berpikir reflektif dimulai dengan kemampuan mengembangkan pengetahuan (Nurul Hidayat et al., 2020). Proses pengembangan pengetahuan siswa perlu didukung dengan pemenuhan kebutuhan belajar salah satunya adalah sumber belajar. Seorang siswa dalam mempelajari permasalahan atau isu sosial-sains memerlukan suatu sumber belajar yang memuat informasi terkini data akurat dan materi yang berfungsi untuk peningkatan literasi (Ely Rohmawati et al., 2018).

Menurut Nizwardi Jalinus dan Ambiyar (2016) penggunaan sumber belajar yang tepat dapat menghasilkan pembelajaran yang berkualitas, menarik dan menyenangkan bagi siswa. Sumber belajar yang sesuai dengan kebutuhan ini adalah sumber belajar berbasis IT, salah satunya adalah weblog. Sulajwo (2017) menyatakan bahwa media pembelajaran berbasis website dapat menumbuhkan daya tarik siswa, dikarenakan media pembelajaran berbasis website ini dilengkapi dengan artikel, link, gambar, dan konten lain yang menarik sehingga siswa dapat terpacu untuk mengakses keseluruhan materi. Berdasarkan alasan tersebut peneliti tertarik melakukan penelitian tentang pengembangan weblog sebagai sumber belajar pada materi pencemaran lingkungan untuk penguatan berpikir reflektif. Tujuan dari penelitian ini adalah untuk mengetahui kemampuan berpikir reflektif siswa SMP melalui penggunaan media weblog pada materi pencemaran lingkungan. Penelitian ini diharapkan dapat memberikan manfaat bagi siswa sebagai sumber belajar tambahan dan memotivasi guru untuk mengembangkan sumber belajar kedepannya.

\section{METODE PENELITIAN}

Penelitian ini dilaksanakan dalam dua tahapan, pertama yaitu pengembangan produk berupa weblog dengan menggunakan desain pengembangan model ADDIE. Model ADDIE dikembangkan oleh Robert maribe Brach, dengan 5 tahapan pengembangan produk yaitu Analyze (Analisis), Design (Desain), Development (Pengembangan), Implement (Implementasi), and Evaluate (Evaluasi). Penelitian pengembangan yang dilakukan peneliti hanya mencapai tahap development (Pengembangan). Weblog selanjutnya divalidasi oleh 4 orang validator yang terdiri dari dua orang dosen dan dua orang guru. Validator melakukan penilaian menggunakan lembar validasi yang terdiri dari validasi materi dan media.

Hasil validasi selanjutnya akan di Uji cobakan untuk melihat respon pengguna terhadap weblog yang dikembangkan. Uji coba terbatas dilakukan dua kali. Uji coba terbatas tahap I atau skala lab dilakukan kepada 10 orang mahasiswa semester 5 Program Studi Pendidikan Biologi FKIP Universitas Riau. Uji coba tahap II dilakukan kepada 20 orang siswa SMPN 4 Pekanbaru. Respon pada uji coba I dan II dikumpulkan menggunakan kuisioner. Berikut tahapan pengembangan model ADDIE pada Gambar 1 .

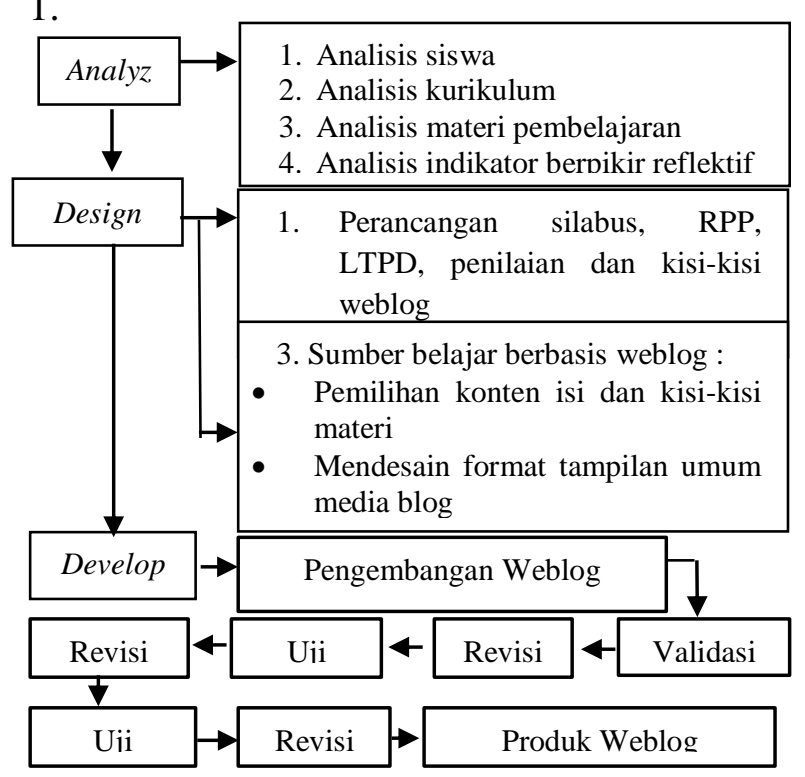

Gambar 1. Tahapan Penelitian Pengembangan Model ADDIE 
Kemampuan berpikir reflektif siswa dikumpulkan menggunakan tes multiple choice yang telah dikembangkan berdasarkan indikator berpikir reflektif yaitu reacting, elaboration dan contemplating. Tes tersebut dilaksanakan untuk materi pencemaran lingkungan dengan masing-masing soal berjumlah 10 butir. Hasil kemampuan berpikir reflektif dari pre-test dan post-test tersebut selanjutnya selanjutnya dianalisis untuk melihat perbandingan perolehan nilai rata-rata kedua tes. Kemudian dianalisis perolehan nilai untuk tiap aspek kemampuan berpikir reflektif (reacting, elaboration dan contemplating), melalui hasil jawaban benar dari tiap soal pada indikator tersebut. Data dihitung menggunakan rumus rerata dan dikelompokkan berdasarkan tingkat kemampuan berpikir reflektif siswa. Rentang kemampuan berpikir reflektif dapat dilihat pada tabel 1 .

Tabel 1. Rentang Nilai Berpikir Reflektif

\begin{tabular}{ccc}
\hline No & $\begin{array}{c}\text { Rentang } \\
\text { Nilai }\end{array}$ & $\begin{array}{c}\text { Tingkat Berpikir } \\
\text { Reflektif }\end{array}$ \\
\hline $\mathbf{1}$ & $0 \leq \mathrm{x} \leq 60$ & Rendah \\
\hline $\mathbf{2}$ & $60 \leq \mathrm{x} \leq 75$ & Sedang \\
\hline $\mathbf{3}$ & $75 \leq \mathrm{x} \leq 100$ & Tinggi \\
\hline
\end{tabular}

(Adaptasi : (Prihatini. H., 2019)

\section{HASIL DAN PEMBAHASAN}

Blog yang telah dikembangkan terdiri dari desain, konten dan artikel. Desain weblog dipilih dan disesuaikan dengan topik materi. Konten weblog yang dikembangkan terdiri dari gambar, poster dan artikel. Artikel weblog terdiri dari 7 kali pertemuan dengan total 10 artikel, setiap artikel dilengkapi dengan link berita yang langsung ditautkan ke website berita. Tampilan weblog dapat dilihat pada gambar 2 .

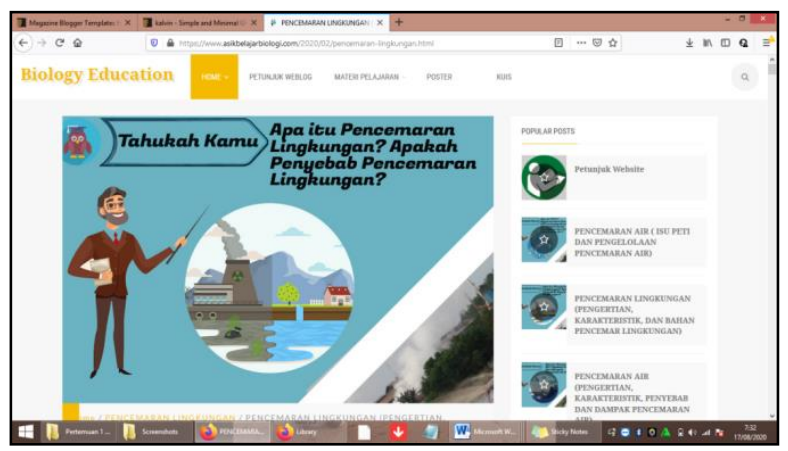

Gambar 2. Tampilan Weblog Pembelajaran

Hasil validasi weblog sebagai sumber belajar untuk meningkatkan kemampuan berpikir reflektif diperoleh berdasarkan validasi materi dengan 4 aspek penilaian yaitu pembelajaran, isi isi, kurikulum, dan berfikir reflektif. Dari validasi tersebut diperoleh persentase rata-rata sebesar $86,3 \%$ dengan kategori sangat layak. Validasi media dengan 3 aspek penilaian yaitu desain umum weblog, isi weblog, dan kegunaannya mendapatkan persentase rata-rata $87,27 \%$ dan dikategorikan sangat layak, hasil ini dapat dilihat pada Tabel 2 dan 3.

Tabel. 2 Rekapitulasi Hasil Validasi Materi

\begin{tabular}{clcl}
\hline No & Aspek & Persentase(\%) & Kategori \\
\hline $\mathbf{1}$ & Pembelajaran & 86 & Sangat Layak \\
\hline $\mathbf{2}$ & Konten Isi & 85,5 & Sangat Layak \\
\hline $\mathbf{3}$ & Kurikulum & 86,3 & Sangat Layak \\
\hline $\mathbf{4}$ & Berpikir Reflektif & 86,3 & Sangat Layak \\
\hline & Rerata & 86,3 & Sangat Layak \\
\hline
\end{tabular}

Tabel. 3 Rekapitulasi Hasil Validasi Media

\begin{tabular}{clcl}
\hline No & Apek & Persentase (\%) & Kategori \\
\hline $\mathbf{1}$ & Desain & 88,5 & Sangat Layak \\
\hline $\mathbf{2}$ & Konten & 88 & Sangat Layak \\
\hline $\mathbf{3}$ & Penggunaan & 85,4 & Sangat Layak \\
\hline & Rerata & 87,27 & Sangat Layak \\
\hline
\end{tabular}


Berdasarkan Tabel 2, materi yang memperoleh persentase tertinggi $(86,3 \%)$ adalah aspek kurikulum dan pemikiran reflektif. Aspek memperoleh nilai penilaian tertinggi karena materi yang disusun dalam artikel weblog sudah sesuai dengan ketentuan kurikulum. Hasil tersebut sesuai dengan prinsip media pembelajaran yang disampaikan oleh Ani Cahyadi (2019) bahwa media pembelajaran yang baik mempunyai prinsip kesesuaian antara materi yang disajikan dengan tujuan pembelajaran dan karakteristik peserta didik. Materi yang dikembangkan dalam weblog disusun dengan menggunakan kerangka berpikir reflektif. Konten tambahan dalam artikel seperti gambar, poster, kasus dan link berita yang mengungkap masalah lingkungan berfungsi sebagai sarana untuk mengembangkan keterampilan eksplorasi pengetahuan siswa. H. Fitriani, et al. (2019) menyatakan bahwa kemampuan menggali pengetahuan tersebut akan membantu mengembangkan kemampuan berpikir kritis dan analisis yang terdiri dari interpretasi masalah yang baik, kemampuan menjelaskan dan pengaturan diri.

Validasi media weblog mendapatkan kategori tertinggi pada aspek desain dengan persentase $88,5 \%$. Weblog yang dikembangkan memiliki desain yang sederhana namun tetap menarik untuk dilihat dan konten artikel tertata dengan baik. Perkembangan desain weblog dilihat dari penggunaan gambar background, layout menu dan layout artikel yang disesuaikan dengan kebutuhan dan kerapian media. Sesuai dengan yang disampaikan oleh Su Rahman (2018) bahwa desain website yang baik adalah desain yang sederhana tetapi tidak rapi dan isi artikel tertata dengan baik. Hasil keseluruhan menunjukkan bahwa weblog dapat digunakan sebagai sumber belajar materi pencemaran lingkungan.

Validasi weblog didukung oleh hasil uji coba 1 kepada mahasiswa Universitas Riau. Hasil penelitian menunjukkan bahwa weblog yang dikembangkan mendapat kategori sangat baik dengan skor 98,5. Skor tersebut menunjukkan bahwa berdasarkan penilaian siswa setelah menggunakan weblog mendapatkan respon yang baik. Responden menyatakan weblog yang dikembangkan menarik, materi yang disajikan sesuai dengan materi pelajaran di sekolah terkait fakta dan pengembangan pengetahuan yang mendukung keterampilan berpikir. Hasil analisis nilai pretest dan post-test siswa menunjukkan perkembangan keterampilan berpikir reflektif. Rata-rata nilai pre-test awal yang diperoleh adalah 69,5 termasuk dalam kategori sedang. Nilai rata-rata mengalami peningkatan pada pelaksanaan post-test dengan nilai rata-rata 82 dan berada pada kategori baik. Gambaran hasil pre-test dan post- test masing-masing indikator berpikir reflektif dapat dilihat pada Gambar 3.

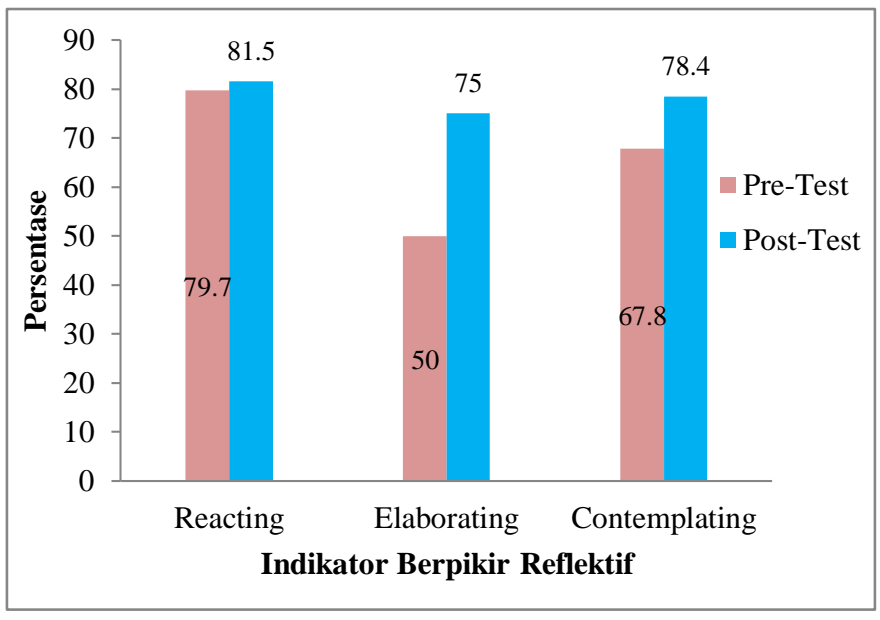

Gambar 3. Penjabaran Kemampuan Berpikir Reflektif Siswa Dari Hasil Tes

Diagram tersebut menunjukkan adanya peningkatan kemampuan berpikir reflektif siswa untuk tiap indikator setelah mengakses konten artikel weblog. Perolehan rata-rata nilai pre-test awal rendah dengan skor hasil jawaban pada tiap indikator reacting $(79,7)$ kategori tinggi, elaboration (50) kategori rendah dan contemplating $(67,8)$ kategori sedang. Hasil ini menggambarkan sebagian besar siswa hanya mampu menjawab soal untuk indikator reacting atau tahap terendah pada berpikir reflektif. Soal dengan indikator reacting berkaitan dengan pengetahuan dasar mengenai pencemaran lingkungan. Selanjutnya perolehan jawaban pada indikator elaboration dan contemplating masih rendah, karena sebagian siswa menjawab salah untuk soal yang meminta siswa menganalisis, 
menguraikan dan mendeteksi kesalahan. Menurut Dewey dalam Lailatun Nisak, (2013) untuk mencapai kemampuan berpikir reflektif siswa harus memiliki kemampuan mengorganisasikan pengetahuannya dan menghasilkan suatu keputusan. Berdasarkan hasil tersebut mengindikasikan bahwa pengetahuan siswa belum terorganisasi dengan baik sehingga siswa kesulitan saat melakukan kegiatan analisis, menguraikan dan merangkum suatu permasalahan. Eray Eğmir dan İjlal Ocak, (2020) menyatakan bahwa kemampuan siswa rendah saat menjawab soal berkaitan dengan berpikir reflektif dikarenakan siswa tidak menggunakan penalaran dan keterampilan evaluasi dalam proses pemecahan masalah.

Perolehan nilai post-test setelah siswa mengakses artikel weblog menunjukkan adanya perubahan positif pada rata-rata nilai siswa. Secara keseluruhan rata-rata post-test mendapatkan skor 82 dengan kategori baik. Jabaran untuk tiap indikator berpikir reflektif siswa reacting $(81,5)$ kategori tinggi, elaboration (75) kategori tinggi dan contemplating $(78,4)$ kategori tinggi. Hasil tersebut menunjukkan kemampuan berpikir reflektif siswa untuk tiap indikator atau tahapan berpikir mendapatkan kategori tinggi walaupun tahap elaboration dan contemplating masih berada dibawah indikator reacting. Peningkatan nilai rerata jawaban untuk indikator elaboration dan contemplating tampak pada beberapa soal yang mencirikan indikator tersebut seperti, mengalisis wacana, menguraikan permasalahan dan mendeteksi kesalahan pada kegiatan yang disampaikan dalam wacana. Analisis dari soal-soal tersebut menunjukkan sebagian besar siswa telah mampu menjawab dengan benar. Proses berpikir reflektif pada tahap refleksi adalah mampu menganalisis suatu keadaan, memberikan penilaian, dan merekomendasikan langkah selanjutya (Rindu Alriavindra Funny et al. 2019)

Perkembangan kemampuan berpikir reflektif tidak dapat terjadi secara langsung, melainkan perlu pengembangan lebih lanjut secara bertahap. Sesuai dengan yang dinyatakan oleh A Salido dan D Dasari,
(2018) bahwa berpikir reflektif terjadi secara bertahap mulai dari tindakan kebiasaan, pemahaman, refleksi dan refleksi kritis. Tindakan kebiasan dan pemahaman diperoleh dari pencarian informasi dengan mengembangkan rasa ingin tahu siswa. Pengembangan awal kemampuan berpikir reflektif juga dapat dilakukan dengan pembiasaan siswa belajar tentang materi berbasis masalah. Menurut Meni Elpita dan Irwandi, (2019) berpikir reflektif tidak terlepas dari kemampuan berpikir kritis, oleh karena itu materi pembelajaran berbasis masalah sangat cocok untuk perkembangan berpikir reflektif siswa. Pembelajaran berbasis masalah akan mengajak siswa mengembangkan kemampuan menganalisa, menimbang, mengambil keputusan dan melakukan penyelesaian masalah. Materi weblog yang dikembangkan dengan merujuk berbagai isu lingkungan, dapat membantu siswa untuk mencari informasi dan mengembangkan pengetahuan tentang permasalahan mengenai lingkungan.

Hasil tes tersebut didukung dengan respon siswa terhadap penggunaan produk weblog, berdasarkan hasil tersebut tampak siswa memberikan respon yang baik terhadap pengembangan produk weblog. Rekapitulasi hasil responden terhadap weblog yang telah dikembangkan untuk setiap aspek penilaian dapat dilihat pada Tabel 4 berikut

Tabel 4. Hasil Rekapitulasi Angket Respon Uji Coba 2 Terhadap Weblog yang Dikembangkan

\begin{tabular}{clcc}
\hline No & \multicolumn{1}{c}{ Aspek } & Skor & Kategori \\
\hline $\mathbf{1}$ & $\begin{array}{l}\text { Tampilan dan } \\
\text { Penggunaan }\end{array}$ & 92,8 & SB \\
\hline $\mathbf{2}$ & Materi & 93,3 & SB \\
\hline $\mathbf{3}$ & $\begin{array}{l}\text { Berpikir } \\
\text { Reflektif }\end{array}$ & 92,8 & SB \\
\hline & Rerata & 93,01 & SB \\
\hline
\end{tabular}

Ket $=$ SB (Sangat Baik)

Respon siswa sebagai pengguna weblog untuk aspek berpikir reflektif mendapatkan rata-rata sebesar 92,8 dengan kategori sangat baik. Penjabaran materi blog dengan menggunakan indikator berpikir reflektif 
direspon dengan baik oleh siswa. Pernyataan negatif yang menyatakan bahwa materi weblog tidak mengaitkan dengan permasalahan yang dapat dijumpai di lingkungan, materi tidak menyelesaikan permasalahan berkaitan dengan lingkungan dan tidak membantu untuk mengumpulkan informasi fakta dan data ditolak oleh siswa. Sebaliknya, siswa memberikan komentar seperti "menggunakan weblog yang telah dikembangkan ini membuat saya mampu menjelaskan dan mengaitkan permasalahan berkaitan materi pencemaran lingkungan". Aspek berikutnya yang mendapatkan respon postif dari siswa yaitu aspek materi dengan skor yang sama sebesar 92,8 kategori sangat baik. Materi weblog disajikan dengan runtut berdasarkan hasil pemaparan KD dan disesuaikan dengan capaian tujuan pembelajaran. Materi weblog juga dikembangkan dengan penambahan konten gambar, poster dan link yang terhubung dengan website lain mempermudah siswa dalam mempelajari materi. Hasil komentar siswa menyatakan bahwa materi dan konten membantu untuk mempelajari topik pencemaran dan pemanasan global, tambahan poster, gambar dan peta konsep juga menarik dan membantu siswa memahami materi . Hal tersebut juga sesuai dengan penelitian yang dilakukan oleh Fitroh Dwi A.H et al. (2013) materi yang sesuai dalam pengembangan weblog dengan tampilan dan desain media akan memberikan respon positif serta meningkatkan minat belajar siswa. Lia Umi Nurayati et al. (2016) juga menambahkan bahwa penyajian materi yang sistematis dan sesuai dengan pengetahuan siswa akan memudahkan siswa untuk belajar.

Aspek terakhir yang dinilai yaitu tampilan dan penggunaan. Aspek ini mendapatkan skor tertinggi yaitu sebesar 93,3 kategori sangat baik. Respon siswa pada aspek tampilan dan penggunaan positif dengan beberapa komentar menyatakan bahwa weblog sangat baik, menarik perhatian siswa untuk mengakses konten lebih banyak dan mudah digunakan karena dapat diakses langsung. Weblog adalah media yang memanfaatkan internet dalam proses pengaksesan informasinya. Jaringan internet menurut Yoka Ifana Putra, (2015) memiliki kelebihan penggunaan yang praktis untuk mencari informasi kapan saja dan dimana saja. Kesesuaian penggunaan media dengan kebutuhan siswa juga disampaikan oleh Andi Prastowo, (2018) bahwa aspek sumber belajar yang dibutuhkan siswa diantaranya adalah dapat dipelajari dimana saja dan kapan saja saat dikehendaki dan dapat digunakan secara mandiri. Hasil respon secara umum menunjukkan bahwa weblog yang dikembangkan menarik bagi siswa dan artikel yang dikembangkan di dalam weblog membuat siswa tertarik dan ingin mencari tahu tentang materi yang disajikan.

Rasa ingin tahu merupakan langkah pertama yang diperlukan untuk pengembangan kemampuan berpikir reflektif. Respon lain yang mengatakan bahwa setelah menggunakan weblog siswa mampu menjelaskan dan mengaitkan permasalahan berkaitan dengan isu lingkungan. Endah Tri Piyatni et al. (2017) juga menyatakan bahwa berpikir reflektif merupakan kemampuan berpikir tingkat tinggi kegiatan berpikir dimulai dari proses pengamatan, menganalisa, menafsirkan masalah, membuat kesimpulan dan mempertimbangkan tindakan. Kemampuan eksplorasi pengetahuan tersebut akan membantu mengembangkan kemampuan berpikir kritis dan analisis kritis yang terdiri dari kemampuan intrepretasi yang baik terhadap masalah, kemampuan menjelaskan dan regulasi diri (H.Fitriani et al. 2019). Berdasarkan hal tersebut, keingintahuan siswa untuk mempelajari materi dan mencoba menjelaskan permasalahan berkaitan dengan materi sudah mencerminkan terjadinya kegiatan pengembangan kemampuan berpikir siswa untuk menuju kepada kemampuan berpikir reflektif.

\section{KESIMPULAN}

Hasil validasi dan uji coba menunjukkan weblog yang dikembangkan telah layak sebagai sumber belajar pada materi pencemaran dan pemanasan global untuk penguatan berpikir reflektif siswa. 
Penguatan berpikir reflektif siswa setelah penggunaan weblog dilihat dari hasil pre-test dan post-test yang menunjukkan adanya perubahan skor dari kategori rendah dan sedang menjadi kategori tinggi. Hasil penelitian secara keseluruhan menunjukkan weblog sebagai sumber belajar pada materi pencemaran dan pemanasan global untuk penguatan berpikir reflektif siswa sudah layak dan dapat diimplementasikan dalam skala yang lebih luas untuk penguatan kemampuan berpikir reflektif siswa.

\section{DAFTAR PUSTAKA}

Ani Cahyadi. 2019. Pengembangan Media dan Sumber Belajar: Teori dan Prosedur. Laksita Indonesia. Banten

A Salido dan D Dasari. 2019. The Analysis Of Students' Reflective Thinking Ability Viewed By Students' Mathematical Ability at Senior High School. Journal of Physics: Conference Series. 11(57):022121

A.W Subiantoro, N.A. Ariyanti, Sulistyo. 2013. Pembelajaran Materi Ekosistem dengan Socio-Scientific Issues dan Pengaruhnya Terhadap Reflective Judgment Siswa. Jurnal Pendidikan IPA Indonesia. 2(1):41-47.

Ely Rohmawati, Wahono Widodo, Rudiana Agustini. 2018. Membangun Kemampuan Literasi Sains Siswa Melalui Pembelajaran Berkonteks Socio-Scientific Issues Berbantuan Media Weblog. Jurnal Penelitian Pendidikan IPA. 3(1) : 8-13.

Endah Tri Priyatni, Siti Cholisatul Hamidah, Pidekso Adi. 2017. Pembelajaran Reflektif. Tira Smart. Malang.

Eray Eğmir dan İjlal Ocak.2020.Prediction Level of the Fourth Grade Students' Scientific Attitudes on Reflective Thinking Skills for Problem Solving. Journal for Educational Research 4(2): 87-102.
E. Suryawati, F. Suzanti, Zulfarina, A. R. Putriana, L. Febrianti. 2020. The Implementation of Local Environmental Problem-Based Learning Student Worksheets to Strengthen Environmental Literacy. Jurnal Pendidikan IPA Indonesia. 9(2):169178

H. Fitriani, M. Asy'ari, S. Zubaidah, S. Mahanal. 2019. Exploring the Prospective Teachers' Critical Thinking and Critical Analysis Skills. Jurnal Pendidikan IPA Indonesia 8(3):379-390

Juhaevah, F. 2017. Profil Kemampuan Berpikir Reflektif Siswa SMP dalam Memecahkan Masalah Matematika Standar Pisa Ditinjau dari Perbedaan Gender. Jurnal Matematika Dan Pembelajaran 5(2), 221-236.

Lailatun Nisak. 2013. Analisis Kemampuan Berpikir Reflektif Siswa dalam Memecahkan Masalah Berbentuk Semantik, Figural, dan Simbolik pada Pokok Bahasan Fungsi Kelas XI IPA di MAN Nglawak Kertosono Nganjuk. Skripsi. Jurusan Pendidikan Matematika Fakultas Ilmu Tarbiyah dan Keguruan Institut Agama Islam Negeri Sunan Ampel. Surabaya.

Meni Elpita dan Irwandi .2019. Kemampuan Berpikir Reflektif dengan Mengunakan Model PBL Pada Pembelajaran Biologi di SMA Negeri 2 Kepahiang. Prosiding Seminar Nasional Sains \& Entrepreneurship. Semarang: 21 Agustus 2019. Vol.1(1).

Nizwardi Jalinus dan Ambiyar. 2016. Media \& Sumber Pembelajaran. Jakarta: Kencana.

Nurul Hidayat, Budi Usodo,Dewi Retno Sari Saputro. 2020. Reflective Thinking Ability of Junior High School Students of 2 Pleret Viewed from SelfConfidence.International Journal of Multicultural and Multireligious 
Understanding.7(8): 117-123

Prihatini, H. 2019. Analisis Kemampuan Berpikir Reflektif Matematis Siswa MTS. Skripsi. Universitas Islam Negeri Syarifhidayatullah: Jakarta.

Rindu Alriavindra Funny, Muhammad Abdul Ghofur, Wuli Oktiningrum, Ni Luh Sakinah Nuraini. 2019. Reflective Thinking Skills of Engineering Students in Learning Statistics. Journal on Mathematics Education 10(3):445-458

Sulajwo. 2017. Media Pembelajaran Berbasis Web untuk Mata Pelajaran Ilmu Pengetahuan Alam Sesuai dengan Gaya Belajar Siswa. The $5^{\text {TH }}$ Urecol Prociding. Yogyakarta : 18 Februari 2017. Hal. 1215-1219.

Su Rahman. 2018 Cara Mudah Menghasilkan Website Terbaik untuk Usaha Online. PT Elex Media Komputindo Kelompok Gramedia. Jakarta.

Vania Zulfa, Milson Max, Iskar Hukum, Irfan Ilyas. 2016. Isu-Isu Kritis Lingkungan dan Perspektif Global. JGG-Jurnal Green Growth dan Manajemen Lingkungan. 5(1) : 29-40 